\title{
QUALITY COMPETITIVENESS OF LATVIA'S METAL INDUSTRY IN THE IRON AND STEEL PRODUCT GROUPS
}

\author{
Janis Priede ${ }^{1}$, Roberts Skapars ${ }^{2}$ \\ ${ }^{1}$ University of Latvia, Latvia, janis.priede@lu.lv \\ ${ }^{2}$ University of Latvia, Latvia, roberts.skapars@lu.lv \\ cross'ref http://dx.doi.org/10.5755/j01.em.17.1.2268
}

\begin{abstract}
The aim of this paper is to develop framework for evaluation of quality competitiveness of countries exports and to use this framework to examine quality competitiveness of Latvia's metal industry in the iron and steel product groups.

To achieve this aim authors studied topic related scientific literature and used appropriate methods to examine quality competitiveness according to the other researchers and authors own developed approach.

To successfully achieve the aim of the paper and fulfill the tasks set the following research methods were used: 1) monographs method; 2) logical - constructive; 3) statistical analysis techniques: structural analysis and regression analysis; 4) graphical method.

At the end of the paper authors make conclusions about developed methodology of evaluation of quality competitiveness and main conclusions about examined quality competitiveness of Latvia's metal industry in the iron and steel product groups.

Keywords: competitiveness, quality, export, iron, steel.

JEL Classification: E30, F14, M21.
\end{abstract}

\section{Introduction}

Quality is a complex phenomenon and there exist no general accepted definition, which fits every purpose and all the complexities in teal economics.

While competitiveness of enterprises has been studied by many scholars around the world, competitiveness of nations is a relatively new discipline.

Studies of export competitiveness in the world markets are not new. Several attempts to evaluate export competitiveness have been made in the past, primarily in Eastern Europe. In Czechoslovakia, for example, a detailed and comprehensive analysis of the study was undertaken already in the 1960's (see, for example, Klacek and Pleva, 1967). Similar approach was used by World Bank studies of the price and quality competitiveness of exports by other authors (Drabek, Olechowski, 1989).

Quality competitiveness topic is still important and research in this field continuous. Researchers are using different methods to look at the quality of exports and its competitiveness. Researchers are developing different methods and indicators to measure quality competitiveness of exports (Aiginger, 2001; Davidsons, Kanepajs, 2008), product differentiation and quality link to changes in exports (Kandogan, 2003, 2004), product-quality view (Hallak, 2006), exporters behavior under quality constrains (Hallak, Sivadasan, 2009).

Main problem authors are facing in this article is measuring quality competitiveness of countries and industries. Until now there are several approaches in the literature how to measure quality competitiveness of countries or industries or product groups and each one of them has their advantages and disadvantages. Approach is still discussable due to the nature of measuring quality itself and measuring quality competitiveness of country is still quite new and undeveloped field.

\section{Theoretical framework of quality competitiveness of country and industry}

Theoretical and empirical research increasingly point to the importance of product quality in international trade and economic development (Hallak, Schott, 2008).

Studies of export competitiveness in the world markets are not new. Several attempts to evaluate export competitiveness have been made in the past, primarily in Eastern Europe. In Czechoslovakia, for example, a detailed and comprehensive analysis of the study was undertaken already in the 1960's (see, for example, Klacek and Pleva, 1967). Unfortunately, their study covered only the price competitiveness of Czechoslovak exports in the EEC market and the period 1955-64 and selected manufacturing exports. They estimated export prices realized by Czechoslovak exporters in the EEC market and compared them with export prices of countries for the same products of countries of the European Free Trade Association (EFTA). 
Similar approach was used by World Bank studies of the price and quality competitiveness of exports by other authors (Drabek, Olechowski, 1989).

Quality competitiveness topic is still important and research in this field continuous. Researchers are using different methods to look at the quality of exports and its competitiveness. Researchers are developing different methods and indicators to measure quality competitiveness of export (Aiginger, 2001; Davidsons, Kanepajs, 2008), product differentiation and quality link to changes in exports (Kandogan, 2003, 2004), product-quality view (Hallak, 2006), exporters behavior under quality constrains (Hallak, Sivadasan, 2009) and other issues.

Since product quality is not directly observable from trade data, there is a lack of consensus on an appropriate measure of quality. Researchers have traditionally used various price indices to proxy for quality, but this approach ignores the horizontal aspects of product differentiation. On the other hand, efforts to incorporate horizontal differentiation have been relatively scarce and are somewhat difficult to implement at a more aggregate level.

In this paper authors decided to pay more attention to Aiginger's ideas in order to better understand the theoretical framework of quality competitiveness.

Higher quality is a necessary precondition for high cost producers to stay competitive. Producing the same quality at a higher price or at lower margins is not feasible in the long run. Many European countries have higher wages than the USA and Japan; this cost advantage is even larger if compared to accession countries and to many new competitors in the globalizing world. It is possible to cope with higher wages by increasing productivity, but since technology and managerial skills are also spreading by the investment of multinational firms, this strategy is not always feasible. Producing a higher quality is an alternative as well as a complement to higher productivity. This strategy is however easier in those industries in which buyers differentiate between quality types, while there are other markets in which price competition is the most important competitive mode. "Quality competition" is competitive environment, in which upgrading quality, and increasing the willingness to pay is important relative to competing at low prices (Aiginger).

Activities that upgrade quality are more or better skilled labor, machines, more sophisticated material inputs, but also superior organization on the plant or firm level. Research and development, as well as imitation of the best techniques and processes, may be sources of quality upgrading. Marketing may increase the willingness to pay by providing information about the capabilities of the product or by changing the tastes of consumers. In most, but not all cases, the quality of output is related to the quality of input. Submitting to certifications, setting standards, and benchmarking are other techniques of upgrading the quality of processes, as well as the quality of products, and also market functions. The inputs that help to upgrade quality, economic and political accelerators, are summarized in Figure 1. It also reports on the indictors that signal quality and consequences for market structure.

Quality differs from productivity, as the latter is defined usually in technical (quantitative) terms, like tons per one unit of labor input. If, however, value added is used as a numerator, then the prices and quality of output are taken into account. And if we distinguish between several qualifications for labor, the quality of inputs can be incorporated into the denominator of productivity. Nevertheless, productivity studies focus on the quantity of output with respect to the quantity of inputs, trying to do so for indicators which are as homogenous as possible, while quality explicitly addresses the heterogeneity of outputs produced usually with respect to heterogeneous inputs.

Innovations refer to changes in processes and products. New products are usually products of higher quality.

However, they can be relatively cheaper when better materials or superior production processes are used. Tension between higher quality and lower costs may arise.

Adding a further stage of processing usually increases the quality of the product. The additional stage can make the product more durable, more convenient, more specifically suitable and useful for the consumer, investor or producer. A further stage of processing can be to combine hardware with a software; a tangible product with a service or information. There are some cases, where a further stage of processing decreases the user value by decreasing flexibility or compatibility for some purposes (Aiginger).

Quality and profitability are closely related, insofar as the quality of products will usually raise profitability, both by decreasing the competitive pressure as well as by increasing the willingness to pay. However, quality is mainly a characteristic of the product and profitability a result of the production process and the strategy and organization of firms. There can be a conflict between the quality of the product as measured in objective terms and profitability, if quality raises costs more than it raises the willingness to pay. 
The economic solution is to find the quality that maximizes profits. The resulting "optimal" quality provided may be below that assessed as desirable or feasible by technicians or consumer organizations.

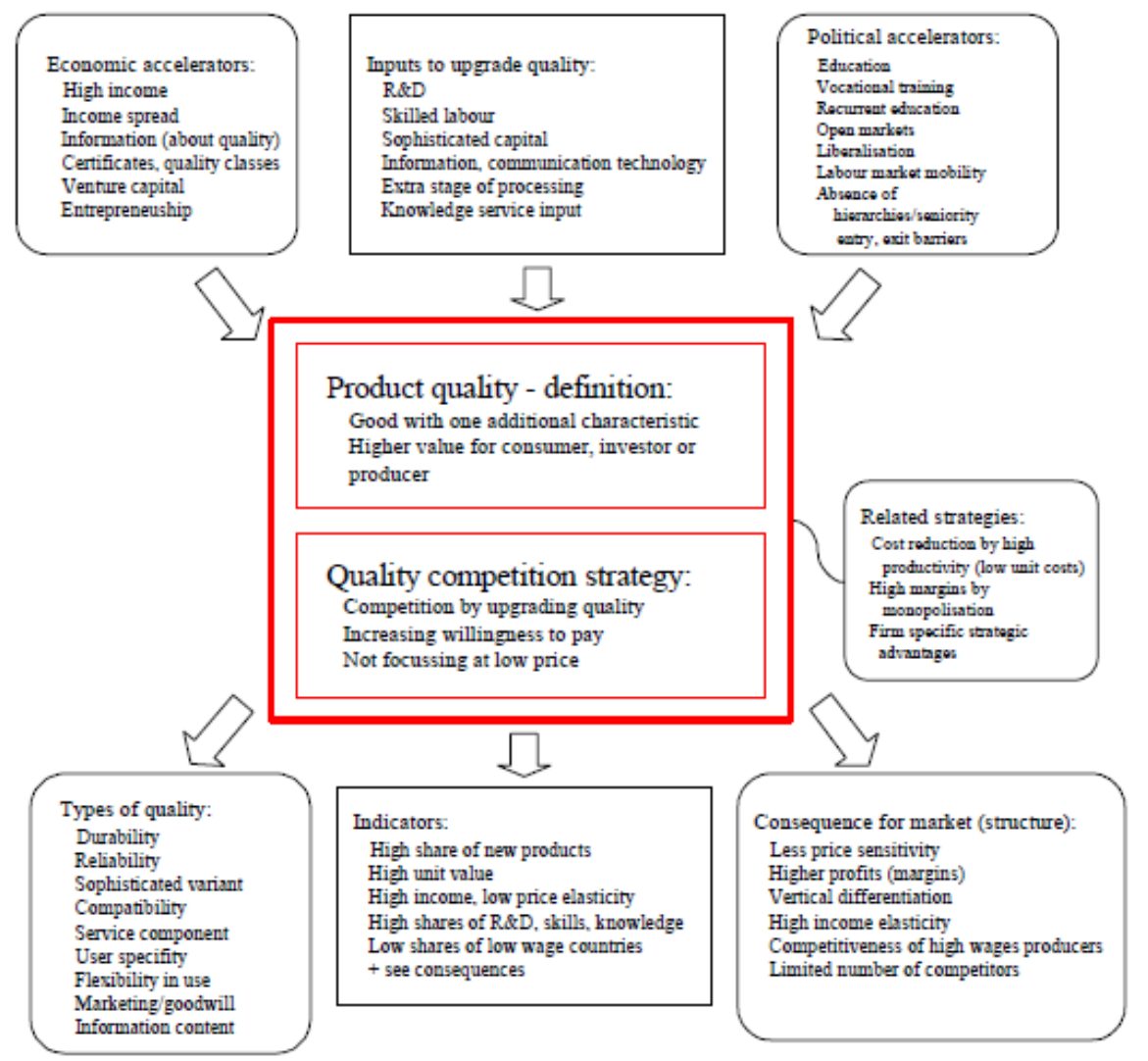

Figure 1. Quality competition: preconditions, types and consequences (Aiginger, 2001)

The quality of products should be reflected in the profits and specifically in the persistence of supernormal profits. If the market is not regulated or characterized by entry barriers, each advantage of a specific firm will be contested rapidly by other firms. Only firms which can consistently upgrade quality or which - to use a term taken from strategic management literature - possess a specific nonimitable advantage can accrue higher profits in the long run.

Aiginger also developed three main indicators to assess quality: the unit value of exports (UV), the share of exports in quality sensitive industries, and the share of exports in the high price (quality) segments.

Authors in this paper are using the unit value (UV) of exports: this indicator is defined as nominal exports divided into tons. Higher unit values reflect higher willingness to pay for a given product, one reason for this is the higher quality in a market with vertically differentiated products. The unit value for an aggregate is higher if a country focus on more sophisticated or higher processed goods. We can call this indicator "indicator on overall quality" since it comprises many different aspects of product quality.

Authors use unit value of imports and relative unit value as well in this paper to reveal nature of quality competitiveness.

\section{Measuring quality competitiveness}

The most comprehensive measure of quality available for empirical research is the "unit value". Its usefulness in evaluating quality comes from the fact that all of the following activities tend to increase sales relative to physical weight (Aiginger):

- Increasing durability, reliability, compatibility, flexibility

- Using superior material inputs or higher skills

- Making a product more specific to demand

- Refining or further processing a product

- Adding new functions, service or maintenance contracts

- Better design, advertising. 
Unit values as indicators of quality have been used in industry studies for assessing qualitative competitiveness and for discriminating between different components of intra-industry trade.

The unit value is defined as nominal value divided into physical volume. In Aiginger's reports it is the gross value of exports or imports in ECU (euro) divided by kilogram. The unit value in general depends on demand and prices, but specifically it reflects changes in quality, shifts to higher product segments and to other value enhancing features (service component, design and advertising). Therefore, unit value is often applied as an indicator in attempts to measure quality and vertical product differentiation. Like any comprehensive indicator, it has advantages and disadvantages. Among the advantages is its availability at nearly every level of disaggregation (6 digit industries or even 9 digit industries), for any country, and even for bilateral country to country trade flows. It is not available for production. For some industries, some information is missing (differing from country to country), implying careful programming techniques for the correct treatment of nominators and denominators.

As far as the interpretation of the unit value is concerned, it is fascinating that most of the components which add value are included. Industries intensively using physical capital exhibit rather low unit values, since capital is used for example in basic steel industries or in basic chemicals for large-scale production. So capital intensive industries rank lower and skill intensive higher in unit values as compared to productivity or value added per employee. This can also be seen as an advantage when we understand that developed countries rely mostly on skills in their efforts to achieve the competitive edge. On the other hand, some industries have intrinsically higher unit values, while they are neither high tech, nor do they use skilled labour, nor is physical capital involved. For example, this holds for textile and apparel industries, in which the unit values are high, since the weight in tons is low. Here, reprocessing also poses a problem. Goods are shipped into low wage countries and return at a somewhat higher unit value, indicating that the high wage country exports the lower quality product (as compared to the re-imported good). Reservations about the use of unit value also hold for precious metals, where supply is scarce relative to demand. Therefore, jewellery, leather, furs, footwear and apparel are among the top industries, as far as absolute unit value is concerned, without for example any indication of the use of skilled labour or research. However in general, high tech or high skill industries - like aircraft and spacecraft, watches and clocks, TV and radio transmitters and instruments - are also among the industries with the highest export unit values (Aiginger).

A problem in using unit values was that high values could indicate high quality or high costs. A technique proposed by Aiginger (Aiginger, 1997) enables us to disentangle costs and quality at least partially. If unit values reflect costs, the quantity exported must be low for the high cost country. If it reflects quality, then exports are predicted to be high for the country with the higher unit value. Another objection to the use of unit value is that unit values may include the higher margins created by market power. The greatest market power is primarily expected on domestic markets. If unit values on the international market contain market power, this will be based on a major innovation. And if some firms succeed in becoming world monopolists and are not challenged over a long period of time, they will produce in various countries. Unit values of exports and imports are not fully comparable, since both are measured at the border. Imports include trade costs from the point of origin to the border, exports from the mill to the border. The reporting mode has shifted in the last years from customs agencies to firms. A lot of noise and inconsistency on the product level have arisen from these features, but the rich data set enables us to cope with many outliers and errors. But in the most cases, a careful second look at the data, or the exploitation of the very rich data can eliminate distortions or enable an evaluation of their quantitative impact. In general we use total exports if we focus on the comparison of European countries.

\section{Quality competitiveness of Latvia's metal industry in the iron and steel product groups}

Authors in this section of article will analyse quality competitiveness of Latvia's metal industry in the iron and steel product groups by applying approaches described in previous sections.

Mechanical engineering and metalworking sector is one of the leading industrial sectors in Latvia (Figure 2). It produces about $20 \%$ of total manufacturing industry output and value added, as well as is the leading exporting sector in Latvia, accounting for one third of total exports (Association of mechanical engineering and metalworking industries of Latvia, 2012).

Until the end of 2008 the mechanical engineering sector was one of the fastest growing sectors in Latvia, with average annual growth rate reaching 20 percent. The most important growth factors were active development of new export markets, as well as local demand. In the first half of the decade a massive modernisation and introduction of new technologies took place within the sector. 


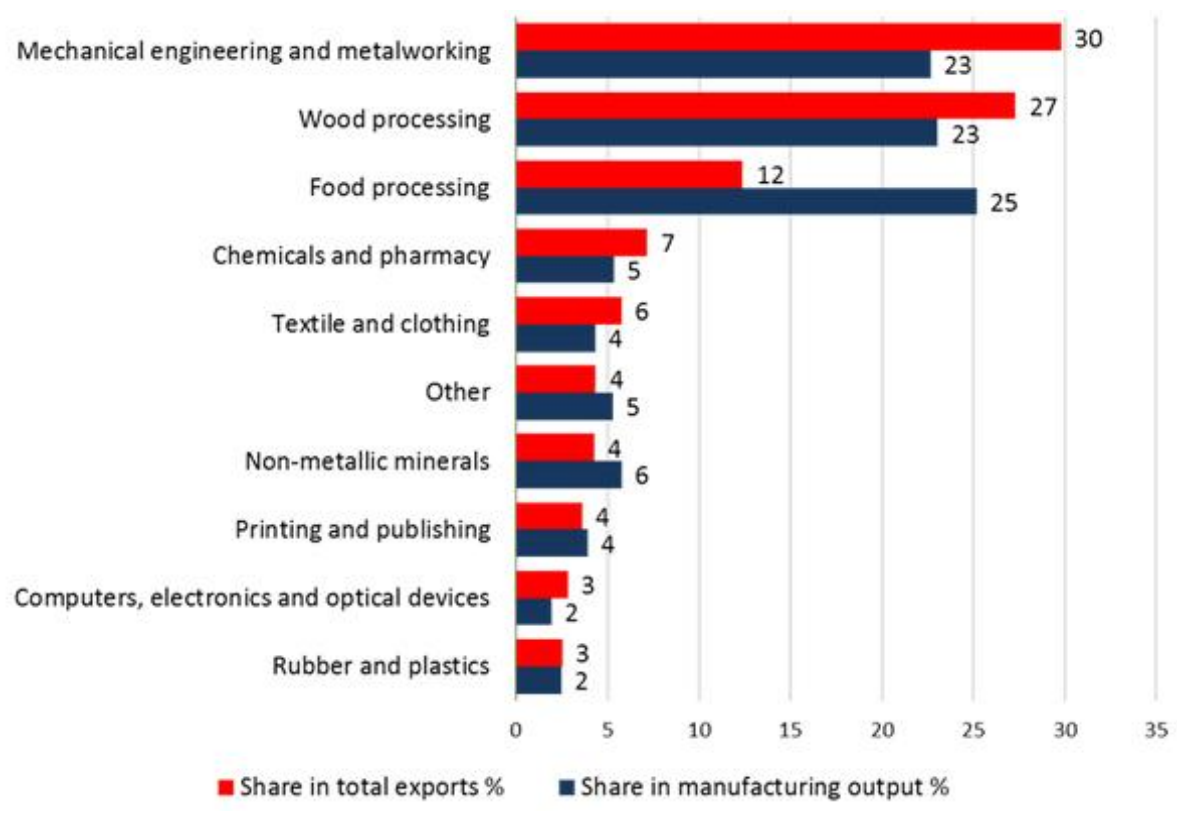

Figure 2. Structure of manufacturing industry in Latvia in year 2011 (Association of mechanical engineering and metalworking industries of Latvia, 2012)

Due to global economic crisis, 2009 was very unavourable for mechanical engineering not only in Latvia, but in most European countries. Following almost decade of fast and stable growth, in 2009 the output droped by about $40 \%$ compared to the levels reached in 2008. The situation was similar in almost all subsectors. The main reasons were reduced demand for equipment and investment goods in other sectors, tough situation in foreign markets (automotive, machine building industries, etc.), drop of demend in local market, especially in construction sector. As a result, the share of local market has decreased and now about $80 \%$ of total output goes to foreign markets.

The lowest point in terms of production ouput was reached in summer 2009. Since beginning of 2010 stabilisation has been observed in the sector.

In 2010 and 2011 there was impressive growth observed in terms of production output. As a result, the prelimenary analysis show that in 2011 the production levels of 2008 have been reached (Figure 3).

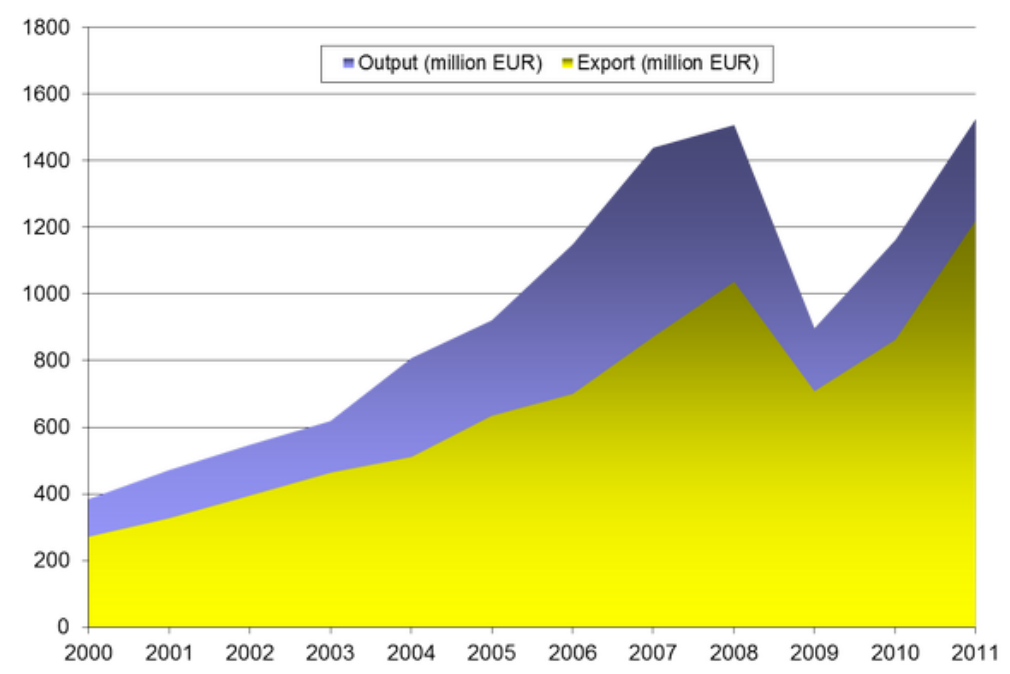

Figure 3. Development trends (output and export) of mechanical engineering and metalworking industry of Latvia, years 2000 - 2011, million EUR

(Association of mechanical engineering and metalworking industries of Latvia, 2012)

Mechanical engineering and metalworking sector is explicitly export oriented as about $80 \%$ of production is sold in foreign markets. According to the official statistics, the sector is exporting to more than 
100 countries worldwide, so the geography of the export markets is really wide. The main markets are neighbouring Baltic countries, Germany, Russia, Nordic countries, as well as other EU and CIS countries. About $70 \%$ of total exports go to EU countries.

According to the statistics provided by Association of mechanical engineering and metalworking industries of Latvia main export markets of Latvia's mechanical engineering and metalworking industry in year 2011 were Lithuania (15\%), Estonia (12\%), Germany (9\%), Russia (7\%), Poland (6\%), Sweden (5\%), Denmark and Norway (4\%), Finland (3\%), UK (2\%), CIS (6\%), other countries (27\%).

To reveal nature of quality competitiveness of Latvia's metal industry in iron and steel product groups authors calculated relative unit value of trade between Latvia and main trade partners: Lithuania, Estonia, Germany and Russia (Figure 4).

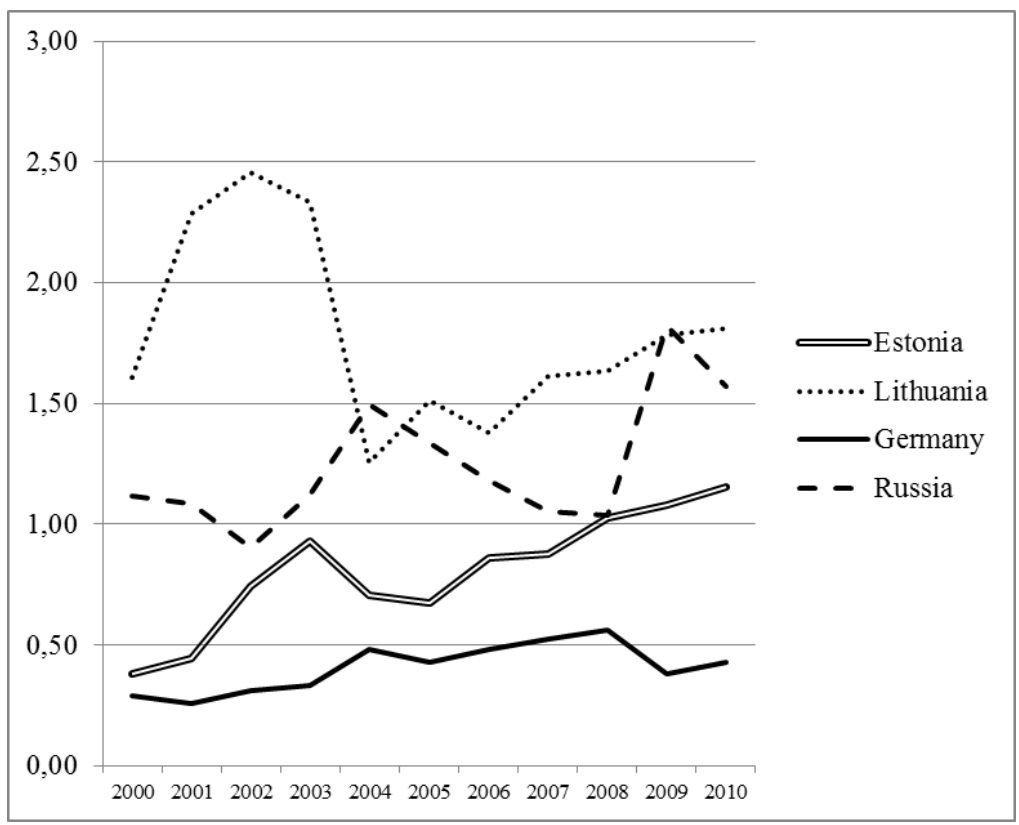

Figure 4. Relative unit value of Latvia's trade with metals (iron and steel) with partner countries: Estonia,

Lithuania, Germany and Russia, years 2000 - 2010 (Authors, Eurostat)

Figure 4 revels relative unit value of trade with iron and steel. According to theoretical framework all indicators above 1,00 (RUV>1,00) tend to indicate competitive trade - export quality and added value is higher than imported. We can see that in the recent years export quality competitiveness is increasing in trade with Estonia and Lithuania - Latvia's main trade partners. Data of trade with Germany shows that imported goods are of much higher quality and added value than imported. Trade data with Russia show that only in year 2002 RUV was below 1,00 but other years it was above 1,00 that indicate higher quality. Of course we do have to take into account that deeper analysis of iron and steel product group will reveal the nature of the trade and "way of added value".

\section{Conclusions}

Measuring quality competitiveness is very complex. Developed approaches by any author have certain drawbacks and researchers have to take them into account. Unit value of export, unit value of import and relative unit value are good indicators to reveal a nature of quality competitiveness.

Mechanical engineering and metalworking industry is one of the most important industries in Latvia. It makes 23\% share in total output of countries production and 30\% of all manufacturing export.

The lowest point in terms of production ouput was reached in summer 2009. Since beginning of 2010 stabilisation has been observed in the sector. In 2010 and 2011 there was impressive growth observed in terms of production output. As a result, the prelimenary analysis show that in 2011 the production levels of 2008 have been reached and that indiacates industries competitiveness in main export markets.

Quality competitiveness of iron and steel was observed with main trade partners - Lithuania and Estonia. Relative unit value of trade (RUV) of iron and steel with Lithuania since year 2000 allways has been above 1,00 and RUV with Estonia is above 1,00 since year 2008. That indcates Latvia's quality competitiveness in main export markets. 


\section{References}

1. Abd-el-Rahman, K. (1991): Firms' Competitive and National Comparative Advantages as Joint Determinants of Trade Composition, Weltwirtschaftliches Archiv 127, 83 - 97.

2. Aiginger, K. (2001): Europe's position in quality competition. Office for official Publications of European Communities, Luxembourg.

3. Aiginger, K. (1997): The qualitative competition of high wage countries. Measuring the position of countries on the quality ladder. Austrian Institute of Economic Research and University of Linz, 19 p.

4. Aiginger, K. (1997): A framework for evaluating the dynamic competitiveness of countries, Structural Change and Economic Dynamics, pp. 159-188.

5. Association of mechanical engineering and metalworking industries of Latvia. www.masoc.lv - accessed: 15.02.2012.

6. Bernard, A. B., Jensen, J. B. (2004): Why Some Firms Export, Review of Economics and Statistics, Vol. 86, No. 2, pp. 561-569.

7. Bils, M., Klenow, P. J. (2001): Quantifying Quality Growth, The American Economic Review, Vol. 91, No.4, pp. 1006.-1030.

8. De Loecker, J. (2007): Do exports generate higher productivity? Evidence from Slovenia, Journal of International Economics, Vol. 73, pp. 69-98.

9. Falkinger, J. (1992): Towards a Quality-Centered Economic Analysis: Some Simple Diagrams, Kyklos, Vol. 45, Issue 4, pp. 469-482.

10. Faruq, H. (2006): New Evidence on Product Quality and Trade, CAEPR Working Paper, No. 2006-019, 40 p.

11. Fun, C. S. (2003): Increasing Returns, Product Quality and International Trade, Economica, Issue 72, pp. 151-169.

12. Garelli, S. (2006): Changing the mindset of competitiveness., http://www.imd.ch/ research/challenges/TC06006.cfm - accessed: 01.02.2012.

13. Grossman, G. M., Helpman, E. (1991): Quality Ladders and Product Cycles, Quarterly Journal of Economics, Vol. 106, Issue 2, pp. 557-586.

14. Hallak, J. C. (2006): Product Quality and the Direction of Trade, Journal of International Economics, Vol. 68, pp. 238-265.

15. Hallak, J. C., Schott, P. K. (2008): Estimated cross-country differences in product quality. National Bureau of Economic Research, Cambridge.

16. Hallak, J., Sivadasan, J. (2009): Firms' Exporting Behavior under Quality Constraints, IPC Working Paper Series, University of Michigan, $64 \mathrm{p}$.

17. Hummels, D., and P. Klenow (2005): The Variety and Quality of a Nation's Exports, American Economic Review $95,704-723$.

18. Hummels, D., and A. Skiba (2004): Shipping the Good Apples Out: An Empirical Confirmation of the AlchianAllen Conjecture, Journal of Political Economy 112, 1384 - 1402.

19. Kandogan, Y. (2003): Does Product Differentiation Explain The Increase in Exports of Transition Countries?, William Davidson Institute Working Papers, University of Michigan Business School, 23 p.

20. Kandogan, Y. (2003): The Reorientation of Transition Countries' Exports: Changes in Quantity, Quality and Variety, William Davidson Institute Working Papers, University of Michigan Business School, 42 p.

21. Kandogan, Y. (2004): How Much Restructuring did the Transition Countries Experience? Evidence from Quality of their Exports. William Davidson Institute Working Papers, University of Michigan Business School, 32 p.

22. Linder, S. (1961): An Essay on Trade and Transformation, Stockholm: Almqvist \& Wiksell.

23. Martin, J., and V. Orts (2001): Vertical Specialization and Intra-Industry Trade: The Role of Factor Endowments, Weltwirtschaftliches Archiv 121, 176 - 189.

24. Ministry of Economics of the Republic of Latvia (2011): Economic Development of Latvia, LLC Latgales druka, $142 \mathrm{p}$.

25. Mora, D. (2002): The Role of Comparative Advantage in Trade within Industries, Weltwirtschaftliches Archiv 138, $291-316$.

26. Murphy, K. M., Shleifer, A. (1997): Quality and Trade, Journal of Development Economics, Vol. 53, pp. 1-15.

27. Pillania, R. K. (2009): Competitiveness and emerging markets, Business Strategy Series. Vol.10, Issue 2, pp. 9095.

28. Porter, M. (1990): Competitive Advantage of the Nations. - New York, Free Press, 857 p.

29. Porter, M. (2005): Building the Microeconomic Foundations of Prosperity: Findings from the Business Competitiveness Index. Harvard University, Harvard.

30. Reiljan, J., Hinrikus, M. (2000): Key issues in defining and analyzing the competitiveness of a country, Tartu University Press, Tartu. 